\title{
PERJANJIAN INTERNASIONAL OLEH DAERAH SEBAGAI KEWENANGAN OTONOMI DAERAH
}

\author{
Noer Indriati \\ Fakultas Hukum Universitas Jenderal Soedirman Purwokerto, Jawa Tengah
}

\begin{abstract}
Law number 32 year 2004 on Regional Government suggests need to do adjustment authority implementation Foreign Relations and Cooperation. Along with the entry into force of the regional autonomy act, the policy of foreign relations and diplomacy by the Central Government, among others, also aimed at empowering and promoting regional potentials. The freedom to conduct foreign relations and cooperation, did not rule on the future more increased in line with the will of Autonomous District and the City to obtain added value for the Autonomous Region concerned. The mechanism of cooperation carried out in consultation with and coordination of the Ministry.
\end{abstract}

Keywords: treaty, sister's city and sister's province

\begin{abstract}
Abstrak
Undang-Undang nomor 32 tahun 2004 tentang Pemerintahan Daerah menyarankan perlu dilakukannya penyesuaian kewenangan dari pelaksanaan kerjasama dan hubungan luar negeri. Seiring dengan berlakunya Undang-Undang otonomi daerah tersebut, kebijakan hubungan luar negeri dan diplomasi oleh Pemerintah Pusat ditujukan untuk memberdayakan dan mempromosikan potensi daerah. Kebebasan untuk melakukan kerjasama dan hubungan luar negeri tidaklah menutup kemungkinan menjadi lebih meningkat sejalan dengan kehendak dari otonomi Kabupaten dan Kota guna mendapatkan nilai tambah bagi daerah otonom yang bersangkutan. Mekanisme kerjasama dilakukan dengan konsultasi dan koordinasi dari pihak kementerian.
\end{abstract}

Kata kunci: perjanjian, perjanjian oleh kabupaten/kota dan perjanjian oleh provinsi

\section{Pendahuluan}

Perwujudan atau realisasi hubungan internasional dalam bentuk perjanjian-perjanjian internasional, sudah sejak lama dilakukan oleh Negara-negara dalam masyarakat internasional. Perjanjian internasional tersebut merupakan hukum yang harus dihormati dan ditaati oleh pihak-pihak yang bersangkutan. Dengan kata lain, bahwa selama masih tetap berlangsungnya hubungan antar bangsa atau negara di dunia ini, selama itu pula masih tetap akan selalu muncul perjanjian internasional. Pasang surutnya perjanjianperjanjian internasional tergantung pada pa- sang surutnya hubungan antar Negara atau bangsa.

Substansi yang diatur dalam perjanjianperjanjian internasional tidak hanya masalahmasalah dan objek-objek yang ada di bumi saja. Memang dalam situasi kemajuan teknologi seperti sekarang ini, sangat memungkinkan bagi masyarakat internasional untuk mengadakan perundingan-perundingan tentang masalah dan kemudian merumuskannya dalam bentuk perjanjian internasional. Peranan hukum internasional pada umumnya, perjanjian internasional pada khususnya dalam mengatur hubungan-hubungan internasional semakin 
lama semakin dirasakan pentingnya, terutama sejak permulaan abad keduapuluh.

Sejalan dengan perkembangan atau kemajuan teknologi para pelaku hubungan internasional juga meluas. Perubahan-perubahan mendasar yang terjadi dalam proses tersebut, dilingkup nasional, regional maupun global telah menuntut kebijakan dan perangkat baru dalam pelaksanaan hubungan antar negara.

Kemajuan teknologi komunikasi telah mendorong globalisasi saling ketergantungan antar negara dan antar masalah yang semakin erat. Hal ini mengakibatkan terciptanya suatu dunia tanpa batas (boderless world) yang seolah-olah telah membentuk suatu global village bagi masyarakat dunia.

Pemerintah telah mengundangkan Undang-undang No. 37 tahun 1999 tentang Hubungan Luar Negeri dan Undang-undang No. 24 tahun 2000 tentang Perjanjian Internasional. Kedua undang-undang ini memberikan landasan hukum yang kuat bagi penyelenggaraan hubungan luar negeri, pelaksanaan politik luar negeri dan pembuatan perjanjian internasional. Kedua perangkat hukum ini menandai dibukanya paradigma baru bagi Indonesia dalam melakukan hubungan luar negeri untuk memenuhi tuntutan jaman yang bergerak cepat. Dengan terjadinya paradigma baru ini, tentu mengubah pemahaman yang selama ini ada bahwa hubungan luar negeri merupakan monopoli negara.

Hubungan internasional yang berkembang sebagai akibat kemajuan teknologi menyebabkan para pelaku hubungan internasional juga meluas, tidak hanya mencakup negara (state actors) saja, akan tetapi telah meluas pada aktor-aktor selain negara (non state actors) seperti: organisasi internasional, Lembaga Swadaya Masyarakat, perusahaanperusahaan multinasional (MNCs), media, daerah, kelompok-kelompok minoritas, bahkan individu. Bermacam-macamnya aktor yang terlibat dalam hubungan internasional dan kerjasama luar negeri di samping membuat proses pengambilan keputusan semakin kompleks, tetapi juga membuka peluang bagi pemantapan diplomasi Indonesia.
Undang-undang No. 32 tahun 2004 tentang Pemerintahan Daerah mengisyaratkan perlu dilakukannya penyesuaian kewenangan pelaksanaan Hubungan dan Kerjasama Luar Negeri. Pada prinsipnya pelaksanaan politik Luar Negeri merupakan kewenangan Pemerintah Pusat. Akan tetapi seiring dengan berlakunya undang-undang otonomi daerah tersebut, kebijakan hubungan luar negeri dan diplomasi oleh Pemerintah Pusat antara lain juga diarahkan untuk memberdayakan dan mempromosikan potensi Daerah, dalam kerangka Negara Kesatuan Republik Indonesia (NKRI).

\section{Pembahasan}

\section{Tinjauan terhadap Perjanjian Internasional}

Perjanjian internasional dalam arti umum dan luas meliputi: persetujuan, traktat ataupun konvensi. Perjanjian yang dimaksud adalah:

Kata sepakat antara dua atau lebih subjek hukum internasional mengenai suatu objek atau masalah tertentu dengan maksud untuk membentuk hubungan hukum atau melahirkan hak dan kewajiban yang diatur oleh hukum internasional. $^{2}$

Sedangkan perjanjian internasional dalam arti sempit adalah:

Kata sepakat antara dua atau lebih subjek hukum internasional (negara, tahta suci, kelompok pembebasan, organisasi internasional) mengenai suatu objek tertentu yang dirumuskan secara tertulis dan tunduk pada atau yang diatur oleh hukum internasional

Berdasarkan pengertian tersebut, maka dapat diuraikan beberapa unsur atau kualifikasi yang harus dipenuhi sebagai perjanjian, sehingga dapat disebut sebagai perjanjian internasional, yaitu kata sepakat, subjek-subjek hukum, berbentuk tertulis, objek tertentu, dan tunduk pada atau diatur oleh hukum internasional.

$2 \quad$ Ibid, hlm. 12 
Definisi perjanjian menurut Konvensi Wina 1969, dalam Pasal 2 ayat 1 butir a dijelaskan:

Treaty means an international agreement concluded between States in written from and governed by international law, whether embodied in a single instrument or in two or more related instruments and whatever its particular designation.

Adapun yang dimaksud dengan perjanjian internasional adalah suatu persetujuan/ kesepakatan yang diadakan antara Negaranegara dalam bentuk yang tertulis dan diatur oleh hukum internasional, baik yang berupa satu instrument tunggal atau berupa dua atau lebih instrument yang saling berkaitan tanpa memandang apapun juga namanya. Sedangkan berdasarkan Undang-undang No. 24 Tahun 2000 tentang Perjanjian Internasional disebutkan:

Perjanjian internasional adalah perjanjian, dalam bentuk dan nama tertentu, yang diatur dalam hukum internasional yang dibuat secara tertulis serta menimbulkan hak dan kewajiban di bidang hukum publik. ${ }^{3}$

Undang-undang Nomor 37 Tahun 1999 tentang Hubungan Luar Negeri, dalam Bab I Pasal 1 ayat 3 disebutkan:

Perjanjian internasional adalah perjanjian dalam bentuk dan sebutan apa-pun, yang diatur oleh hukum internasional dan dibuat secara tertulis oleh Pemerintah Republik Indonesia dengan satu atau lebih negara, organisasi internasional atau subjek hukum internasional lainnya, serta menimbulkan hak dan kewajiban pada Pemerintah Republik Indonesia yang bersifat hukum publik

Dari pengertian di atas dapat diketahui bahwa perjanjian internasional merupakan suatu persetujuan yang dapat berbentuk tertulis maupun tidak tertulis, dilakukan oleh negara atau subjek hukum internasional lain, yang diatur dengan menggunakan instrumen

$3 \quad$ Undang-undang No. 24 Tahun 2000 Pasal 1 (ayat 1) tunggal maupun lebih, serta tunduk pada hukum internasional.

\section{Pembuatan Perjanjian Internasional oleh Negara (State Actor)}

Negara masih merupakan subjek hukum yang terpenting dibanding dengan subjeksubjek hukum internasional lainnya. ${ }^{4}$ Negara sebagai subjek hukum internasional, terdapat satu patokan/standart seperti yang tercantum pada Pasal 1 Konvensi Montevideo (Pan American) The Convention on Rights and Duties of State of 1933, yang menentukan:

Negara sebagai subjek dalam hukum internasional harus memiliki (a). penduduk tetap; (b). wilayah tertentu; (c). pemerintahan dan (d). kapasitas untuk berhubungan dengan negara lain. ${ }^{5}$

Dari segi hukum internasional, syarat (d) merupakan syarat yang paling penting. Suatu negara harus memiliki kemampuan untuk menyelenggarakan hubungan-hubungan ekstern dengan negara-negara lain. ${ }^{6}$ Hal inilah yang membedakan negara adalam arti sesungguhnya dengan unit-unit lain atau negaranegara protektorat, negara Federal dan sebagainya.

Suatu negara atau bangsa pastilah memiliki kewenangan atas apa yang ada di bawah, dalam dan atas wilayahnya. Kewenagan tersebut tidak lepas dari kedaulatan internal negara tersebut, karena hal tersebut menunjang dapat atau tidaknya suatu negara mempertahankan kedaulatannya. Terdapat beberapa cara yang harus dilakukan oleh negara untuk memperkuat atau mempertahankan kedaulatannya, yaitu melalui pengembangan kewenangan-kewenangan dalam memanfaat-

4 Lihat Advisory Opinion dari ICJ dalam Reparation Case di mana ICJ secara penuh (unanimously) menyatakan bahwa PBB dapat mengajukan klaim atas pertanggungjawaban internasional terhadap pemerintah yang secara de facto atau de Jure telah melakukan tindakan-tindakan yang merugikannya.

5 Jawahir Thontowi dan Pranoto Iskandar, 2006, Hukum Internasional Kontemporer, Bandung: Refika Aditama, hlm.105

6 JG. Starke, 2006, Pengantar Hukum Internasional 1, Jakarta: Sinar Grafika, hlm. 128 
kan potensi-potensi alamiah maupun nonalamiah negaranya. ${ }^{7}$

Istilah apapun yang digunakan untuk perjanjian internasional yang dibuat, berdasarkan praktik negara-negara, negara Republik Indonesia hanya membedakan perjanjina internasional dalam 2 (dua) golongan. Pada satu pihak terdapat perjanjian internasional yang diadakan menurut tiga tahap pembentukan, yakni perundingan, penandatangan dan ratifikasi. Dan pada lain pihak perjanjian internasional dibuat dengan dua tahap yakni perundingan dan penandatanganan. ${ }^{8}$ Praktik mengenai dua macam perjanjian ini belum jelas sampai diundangkannya suatu Undangundang tentang Perjanjian Internasional. Lepas dari persoalan ini, yang sangat penting juga apabila dilihat dari sudut ketatanegaraan dan politik dalam Negara Indonesia, sematamata dari sudut peristilahan hanya untuk membedakan kedua perjanjian internasional tersebut.

Undang-undang Dasar 1945 menetapkan bahwa yang menjadi pemegang kekuasaan membuat Perjanjian Internasional adalah kerjasama antara lembaga eksekutif dan lembaga legslatif. Hal ini sebagaimana disebutkan dalam Pasal 11 sebagai berikut:

Presiden dengan persetujuan Dewan Perwakilan Rakyat menyatakan perang, membuat perdamaian dan perjanjian dengan negara lain

Selanjutnya sebagai aturan operasional dalam rangka pembuatan dan pengesahan perjanjian internasional, Pemerintah pada tanggal 23 Oktober 2000 telah mengundangkan Undang-undang No. 24 Tahun 2000 tentang Perjanjian Internasional dan juga sebagai pelaksanaan ketentuan-ketentuan Pasal 13 dan Pasal 14 Undang-undang No. 37 Tahun 1999 tentang Hubungan Luar Negeri. Sebelum adanya Undang-undang No. 24 Tahun 2000, dasar pembuatan perjanjian internasional dilaksana-

Mirza Satria Buana, 2007, Hukum Internasional Teori dan Praktek, Bandung: Nusamedia, hlm. 19

8 Mochtar Kusumaatmadja dan Etty Agoes, 2003, Pengantar Hukum Internasional, Bandung: Alumni, hlm. 119 kan dengan Surat Presiden No. 2826/Hk/1960 sebagai pelaksanaan Pasal 11 Undang-undang Dasar 1945. Dengan ketentuan-ketentuan tersebut di atas, sudah jelas bahwa dalam konteks pembuatan perjanjian internasional pemegang "treaty making power" di Indonesia adalah Presiden dan Presiden memberikan wewenangnya kepada Menteri Luar Negeri.

Pembuatan perjanjian internasional dilaksanakan melalui beberapa tahap, yaitu Pertama, ahap Penjajakan. Tahap penjajakan adalah tahan dimana para pihak yang ingin membuata perjanjian menjajaki kemungkinankemungkinan untuk dibuatnya perjanjian internasional. Penjajakan dapat dilakukan melalui inisiatif instansi/lembaga pemerintahan (negara) di Indonesia ataupun dapat pula merupakan inisiatif dari "calon mitra" (counterpart); Kedua, Tahap Perundingan. Tahap perundingan adalah suatu upaya yang ditempuh oleh para pihak yang membuat perjanjian internasional untuk mencapai kesepakatan atas materi yang masih belum dapat disetujui dalam tahap penjajakan. Tahap ini dapat pula dipergunakan sebagai wahana untuk memperjelas pemahaman setiap pihak tentang ketentuan-ketentuan yang tertuang dalam perjanjian internasional; Ketiga, Tahap Perumusan Masalah. Tahap perumusan naskah adalah merupakan hasil kesepakatan dalam perundingan oleh para pihak atas materi perjanjian internasional. Pada tahap ini dilakukan pemarafan terhadap naskah perjanjian internasional yang telah disetujui. Pada tahap ini disusun pula Agreed Minutes of Meeting, Records of Discussion atau Summary Records yang dapat berisi hal-hal yang telah disepakati, hal-hal yang belum disepakati serta tentang perundingan berikutnya. Dalam hal masih ada ketentuan-ketentuan yang belum disepakati, instansi teknis harus senantiasa mengupayakan komunikasi intern yang efektif dengan instansi di dalam negeri dan komunikasi dengan mitra runding melalui Deplu. Komunikasi demikian dapat meliputi usul rumusan baru atau kompromi atau penentuan jadual perundingan; Keempat, Tahap Penerimaan. Tahap perundingan bilateral, 
kesepakatan atas naskah awal hasil perundingan dapat disebut "penerimaan" yang biasanya ditandai dengan pemarafan pada naskah perjanjian internasional oleh ketua masing-maisng delegasi. Proses penerimaan (acceptance/approval) pada perjanjian multilateral merupakan tindakan pengesahan suatu negara pihak atas perubahan perjanjian internasional; Kelima, Tahap Penandatangan. Tahap ini merupakan tahap akhir dari sebuah perundingan untuk melegalisasi kesepakatan yang dituangkan dalam naskah perjanjian internasional. Namun penandatanganan tidak selalu merupakan pemberlakuan perjanjian internasional. Keterikatan akan tergantung pada klausula pemberlakuan yang telah disepakati oleh para pihak dalam sebuah perjanjian. Hal ini tidak hanya berlaku pada perjanjian bilateral namun juga pada perjanjian multilateral.

\section{Perjanjian Internasional Oleh Daerah} Sebagai Wujud Kewenangan Otonomi Daerah

Hubungan dan kerjasama luar negeri oleh Pemerintah Daerah harus diselenggarakan sesuai dengan Politik Luar Negeri, sesuai Konvensi Wina 1961 mengenai Hubungan Diplomatik dan Konvensi Wina 1963 mengenai Hubungan Konsuler. Pemerintah Republik Indonesia mempunyai wakil di luar negeri yang hanya dikenal sebagai Perwakilan Republik Indonesia, yang melayani kepentingan Negara Republik Indonesia termasuk Pemerintah Daerah, karena Pemerintah daerah tidak diperbolehkan membuka Perwakilan tersendiri.

Peluang untuk menyelenggarakan hubungan dan kerjasama luar negeri oleh Daerah Otonom Kabupaten dan Kota sangat dimungkinkan dan terbuka secara luas, baik yang berbentuk sister's city atau sister's province. Hal tersebut terlihat sejak diberlakukannya Undang-undang No. 22 Tahun 1999 tentang Pemerintahan Daerah, yang kemudian diubah dengan Undang-undang No. 32 Tahun 2004, Peraturan Pemerintah No. 25 Tahun 2000 tentang Kewenangan Pemerintah dan Kewenangan Propinsi sebagai Daerah Otonom dan Undang-undang No. 37 Tahun 1999 tentang
Hubungan Luar Negeri. Bab I Ketentuan Umum Pasal 1 point 6 menyebutkan bahwa:

Daerah Otonom yang selanjutnya disebut Daerah, adalah kesatuan masyarakat hukum yang mempunyai batas-batas wilayah yang berwenang mengatur dan mengurus urusan pemerintahan dan kepentingan masyarakat setempat menurut prakarsa sendiri berdasarkan aspirasi masyarakat dalam sistem Negara Kesatuan Republik Indonesia

Berdasarkan prinsip otonomi luas, nyata dan bertanggungjawab, maka kepada Daerah Otonom dapat diberikan wewenang yang luas untuk menyelenggarakan pemerintahan dan mengatur urusan rumah tangganya. Selain itu Pemerintah Daerah Otonom Kabupaten dan Kota juga diberikan wewenang (dan bilamana perlu) dapat mengadakan hubungan dan kerjasama luar negeri dalam rangka usaha untuk memajukan Daerahnya sendiri.

Kebebasan untuk melakukan hubungan dan kerjasama luar negeri, tidak menutup kemungkinan pada masa yang akan datang lebih meningkat sejalan dengan kehendak Daerah Otonom Kabupaten dan Kota untuk memperoleh nilai tambah bagi Daerah Otonom yang bersangkutan. Hal ini merupakan babak baru dalam penyelenggaraan Pemerintah Daerah yang penuh dengan tantangan. Penyelenggaraan otonomi daerah dilaksanakan dengan prinsip-prinsip demokrasi dan memperhatikan keanekaragaman daerah. ${ }^{9}$ Dan kewenangan Daerah Otonom tidak mencakup kewenangan dalam bidang kebijakan strategis untuk penyelenggaraan pemerintahandan hanya melaksanakan pemerintah Pusat yang dilimpahkan. Demikian juga dengan hal-hal yang harus diperjanjikan oleh Daerah adalah dalam batasbatas kewenangan Daerah yang bersangkutan.

Undang-undang No. 32 Tahun 2004 yang menganut prinsip otonomi seluas-luasnya, maka pemberian kewenangan kepada Daerah

9 Syahda Guruh LS, 2000, Menimbang Otonomi Vs Federal - Mengembangkan Wacana Federalisme dan otonomi luas menuju masyarakat Madani Indonesia, Bandung: Pemuda Rosdakarya, hlm. 80 
Otonom diberikan dengan keleluasaan penuh di mana kepada Daerah Otonom dapat menyelenggarakan pemerintahan sebagaimana ditentukan dalam Bab III mengenai Pembagian Urusan Pemerintahan, dari Pasal 10 sampai dengan Pasal 18. Pasal 10 ayat 3 menetapkan bahwa urusan pemerintahan yang menjadi urusan Pemerintah Pusat adalah:
a. politik luar negeri;
b. pertahanan;
c. keamanan;
d. justisi;
e. moneter dan fiskal nasional; dan
f. agama

Sedangkan bidang-bidang lain yang menjadi kewenangan pemerintahan daerah Provinsi merupakan skala provinsi diatur dalam Pasal 13, dan Pasal 14 mengatur kewenangan Kabupaten dan Kota. Bidang-bidang hubungan dan kerjasama luar negeri oleh Daerah memerlukan konsultasi dan koordinasi dengan Departemen Luar Negeri. Bila diringkas antara lain meliputi bidang-bidang kerjasama sebagai berikut:

a. Kerjasama Ekonomi

1. Perdagangan

2. Investasi

3. Ketenagakerjaan

4. Kelautan dan Perikanan

5. Ilmu Pengetahuan dan Teknologi

6. Kehutanan

7. Pertanian

8. Pertambangan

9. Kependudukan

10. Pariwisata

11. Lingkungan Hidup

12. Perhubungan

b. Kerjasama Sosial Budaya

1. Pendidikan

2. Kesehatan

3. Kepemudaan

4. Kewanitaan

5. Olahraga

6. Kesenian

c. Bentuk Kerjasama Lain

Pemerintah Daerah dalam hal ini dilarang melakukan pinjaman langsung kepada pihak lain di Luar Negeri. Pemerintah Pusat menetapkan pinjaman dan/atau hibah luar negeri yang akan diteruspinjamkan atau diterushibahkan kepada Pemerintah Daerah. Pinjaman luar negeri oleh Daerah melalui Pemerintah Pusat diatur tersendiri dalam Peraturan Menteri Keuangan No. 52 Tahun 2006 dan No. 53 Tahun 2006.

Kerjasama luar negeri dilakukan dengan syarat-syarat berupa Pertama, dengan negara yang memiliki hubungan diplomatik dengan Indonesia dan dalam kerangka Negara Kesatuan Republik Indonesia (NKRI); Kedua, sesuai dengan bidang kewenangan Pemerintah Daerah sebagaimana diatur dalam peraturan perundang-undangan nasional Republik Indonesia; Ketiga, mendapat persetujuan dari Dewan Perwakilan Rakyat Daerah (DPRD); Keempat, tidak mengganggu stabilitas politik dan keamanan dalam negeri; Kelima, tidak mengarah pada campur tangan urusan dalam negeri masing-masing negara; Keenam, berdasarkan asas persamaan hak dan tidak saling memaksakan kehendak; Ketujuh, mendukung penyelenggaraan pemerintahan, pembangunan nasional dan Daerah serta pemberdayaan masyarakat. ${ }^{10}$

Secara umum mekanisme pembuatan perjanjian internasional didasarkan pula pada Pasal 5 ayat (1) Undang-undang No. 24 Tahun 2000 yang menentukan agar lembaga negara dan lembaga pemerintah, baik departemen maupun non departemen di tingkat Pusat dan Daerah yang mempunyai rencana untuk membuat perjanjian internasional, terlebih dahulu melakukan konsultasi dan koordinasi mengenai rencana tersebut dengan Menteri Luar Negeri. Hal ini berlaku pada seluruh perjanjian internasional yang bersifat bilateral maupun multilateral. ${ }^{11}$

10 Departemen Luar Negeri Republik Indonesia, 2007, Panduan Umum Tata Cara Hubungan dan Kerjasama Luar Negeri Oleh Pemerintah Daerah Revisi Tahun 2006, Jakarta, hal. 20.

11 Kria Fahmi Pasaribu, 2004, Pembuatan Dan Pengesahan Perjanjian Internasional Dalam Kerangka Undang-undang No. 24 Tahun 2000 Tentang Perjanjian Internasional, Makalah disampaikan pada Pelatihan Nasional "Peningkatan Pengetahuan Dalam Penyusunan Kontrak-kontrak Perjanjian Internasional Di Era Otonomi Daerah" Di Malang, hal. 6. 
Mekanisme hubungan dan kerjasama luar negeri atas prakarsa Pihak Indonesia yang dilakukan oleh Pemerintah Daerah atau pihakpihak lain (non state actors), adalah Pertama, Pemerintah Daerah sebagai instansi pemrakarsa melakukan koordinasi dengan Departemen Luar Negeri serta instansi terkait dan mengajukan usulan program kerjasama yang berisi latar belakang kerjasama, tujuan, sasaran, pertimbangan, potensi daerah, keunggulan komparatif, dan profil pihak asing yang akan menjadi mitra kerjasama; Kedua, Pemerintah Daerah sebagai instansi pemrakarsa dapat mengadakan rapat interdep dengan mengundang Departemen Luar Negeri dan instansi terkait untuk membicarakan usulan program tersebut; Ketiga, Koordinasi dapat juga dilakukan melalui komunikasi resmi surat menyurat; Keempat, Departemen Luar Negeri selanjutnya memberikan pertimbangan politis/ yuridis Hubungan dan Kerjasama Luar Negeri sesuai dengan Kebijakan Politik Luar Negeri Indonesia; Kelima, Departemen Luar Negeri berdasarkan masukan dari perwakilan Republik Indonesia menyediakan informasi yang diperlukan dalam rangka menjalin kerjasama dengan pihak Asing.

Keenam, Departemen Luar Negeri mengkomunikasikan rencana kerjasama dengan perwakilan Diplomatik dan Konsuler pihak asing di Indonesia dan Perwakilan Republik Indonesia di Luar Negeri; Ketujuh, Departemen Luar Negeri memberi-tahukan hasil koordinasi kerjasama dengan Pihak asing kepada instansi terkait di daerah dan Perwakilan Republik Indonesia di Luar Negeri.

Kedelapan, Kesepakatan kerjasama antar pihak Asing dan Daerah dituangkan dalam bentuk Perjanjian Internasional yang lazim digunakan sesuai dengan pertimbangan Departemen Luar Negri. Dalam hal diperlukan Surat Kuasa (full powers) dari Menteri Luar Negeri dapat diberikan setelah dipenuhi persyaratan-persyaratan peraturan perundangundangan yang berlaku; Kesembilan, Departemen Luar Negeri ikut serta memantau dan melakukan evaluasi terhadap tindak lanjut dan pelaksanaan kerjasama. ${ }^{12}$

\section{Penutup}

Pembuatan perjanjian oleh Daerah Otonom merupakan suatu fenomena baru. Hal ini memberikan cakrawala kepada daerah untuk senantiasa menawarkan potensi-potensi yang ada di Daerah, dalam batas-batas kewenangannya, baik kewenangan Kabupaten/kota (sister's city) maupun kewenangan provinsi (sister's province).
12 Departemen Luar Negeri Republik Indonesia, Op Cit, hlm. 21-22 